\title{
KOMPARASI PENDAPATAN USAHATANI PADA BEBERAPA KOMBINASI SISTEM OLAH TANAH DAN PERTANAMAN
}

\author{
Ellys Yuliarti \\ Staf Pengajar Jurusan Sosial Ekonomi Pertanian Fak. Pertanian UNIB
}

\begin{abstract}
This research was conducted in research station at Bogor Agricultural University from october 1992 to July 1993. It was aimed to compare income of farming system under various of land tillage and plant. Analysis of varian was applied to examine the influence of various tillage system the results showed that minimum tillage and conventional could decreser farmers income through in the second season monoculture and multicropping systems.
\end{abstract}

Key words :comparative, farming income, tillage, and cropping

\section{PENDAHULUAN}

Teknologi olah tanah secara sederhana sudah dimulai oleh suku-suku aseli yang ada di Indonesia, yaitu dengan cara menebas dan membakar blukar. Era pengolahan tanah yang lebih modern yaitu secara konvensional (dengan bajak) muncul setelah ditemukannya bajak besi oleh Charles Newbold, 1796 yang menggeser teknologi olah tanah tradisional atau primitif (Utomo 1989). Pemanfaatan ternak atau mesin untuk membajak telah meningkatkan efisiensi produksi. Adanya sistem olah tanah yang berbeda-beda akan memberikan pengaruh kepada tanah itu sendiri sebagai media tumbuh tanaman, sehingga akan berpengaruh kepada produksi tanaman dan selanjutnya pendapatan usahatani. Menurut Larson dan Osborn, 1985 olah tanah konvensional memiliki beberapa kelemahan , antara lain terjadinya erosi. Pada kondisi normal kandungan air tanah selalu lebih rendah dibanding tanpa olah tanah, hasil tanaman ynag diperoleh pada tanah yang beraerasi baik relatif lebih rendah dibanding teknik tanpa olah tanah(Griffith et al, 1977). Disamping itu pencucian hara lebih tinggi dan dekomposisi bahan organik cenderung meningkat (Utomo ,1990) serta mahalnya biaya pengolahan dan kebutuhan energi yang digunakan (Larson dan Osborn,1985) pada kondisi tanah tersebut akan berakibat pada hasil tanaman dan pendapatan usahatani.

Selain sistem olah tanah budidaya lahan kering telah mengenal beberapa sistem pertanaman antara lain sistem monokultur dan tumpangsari (utomo ,1989). Penanaman dua jenis tanaman atau lebih pada sebidang tanah dengan waktu bersamaan disebut tumpang sari, sedangkan bila dilakukan tidak bersamaan disebut tumpang gilir. Sistem tumpang sari banyak 
diterapkan petani kecil di daerah tropika dengan alasan meningkatkan produktivitas tanah dan produksi persatuan luas lebih tinggi dan efektif dalam penggunaan lahan (Hiebsch, 1978). Selain itu sistem tumpangsari dapat meningkatkan pendapatan dan efisien dalam menggunakan input produksi serta memenuhi syarat sebagai salah satu teknologi yang berinput rendah (Cardero dan McCollum, 1978) dan (Sudana dan Basa,1984). Pada pola tanam monokultur terutama tanaman yang tidak menghasilkan bahan organik akan terjadi penurunan bahan organik secara cepat sehingga berpengaruh terhadp produksi tanaman (Utomo, 1989)., namun sampai saat ini masih sering dijumpai budidaya monokultur pada lahan kering terutama bila nilai ekonomi tanaman cukiup tinggi.Penelitian ini bertujuan mengkaji perbandingan pendapatan usahatani pada beberapa sistem olah tanah dan pertanaman.

\section{METODE PENELITIAN}

Penelitian dilakukan di Kebun Percobaan Fakultas Pertanian IPB di Darmaga Bogor. Pada lahan yang diberakan cukup lama dengan kemiringan $4 \%, 6 \%, 10 \%$ masing-masing untuk kelompok I, II, III. Percobaan dilaksanakan pada bulan Oktober 1992 sampai bulan Juli 1993. Percobaan menggunakan Rancangan Acak Kelompok Lengkap Faktorial yang terdidi dari faktor olah tanah dan pertanaman. Faktor olah tanah terdiri dari 3 cara dan faktor pertanaman 3 jenis pertanaman. Penyusunan kelompok atas perbedaan kemiringan.

Rancangan percobaan yang dipergunakan untuk menguji pengaruh kombinasi sistem olah tanah dengan pertanaman dan bera adalah Rancangan Acak Kelompok sederhana. Setiap kelompok terdiri dari 10 perlakuan, yaitu 9 kombinasi olah tanah dengan pertanaman ditambah dengan sistem bera. Perlakuan tersebut diberikan pada musim tanam I. Pertanaman pada musim tanan II adalah sistem Tumpangsari dengan pengolahan tanah minimum pada setiap perlakuan yang digunakan sebagai indikator pengaruh perlakuan pada musim tanam I.Untuk melihat pengaruh sistem olah tanah dan pertanaman digunakan analisis ragam dengan model linier sebagai berikut :

$$
Y i j=\mu+\sigma i+\alpha j+\beta k+(\alpha \beta) j k+\epsilon i j k
$$

dimana :

\begin{tabular}{|c|c|}
\hline Yijk & $\begin{aligned}= & \text { Nilai pengamatan pada kelompok ke-i, sistem olah tanah ke-j dan sistem } \\
& \text { pertanaman ke- } \mathrm{k}\end{aligned}$ \\
\hline$\mu$ & $=$ Nilai tengah umum \\
\hline$\sigma i$ & $=$ Pengaruh kelompok ke-i \\
\hline
\end{tabular}




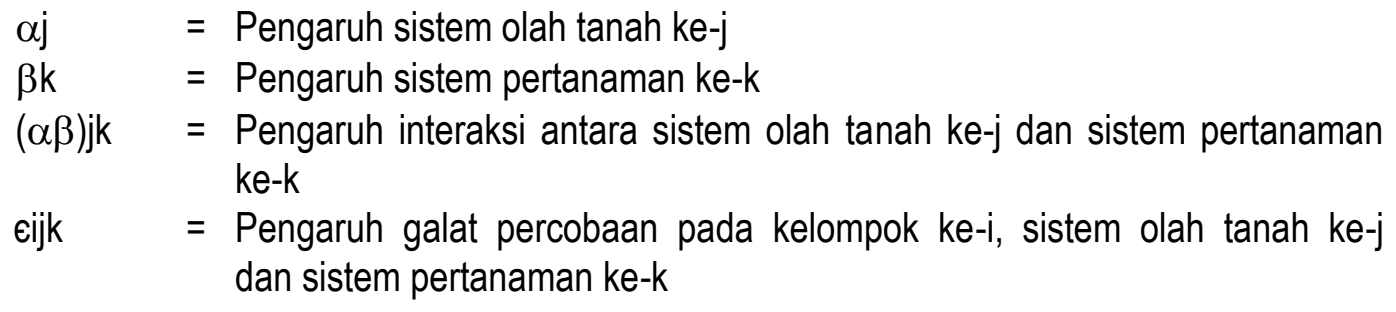

Perbedaan antara perlakuan selanjutnya diuji dengan menggunakan uji beda nyata terkecil ( Steel dan Torrie, 1980).Untuk melihat pengaruh kombinasi sistem olah tanah dan pertanaman serta sistem bera digunakan analisis ragam dengan model linier sebagai berikut :

$$
Y i j=\mu+\sigma i+a j+\varepsilon i j
$$

Dimana :

Yij = Nilai pengamatan pada kelompok ke-i dan perlakuan ke-j

$\mu \quad=$ Nilai tengah umum

$\sigma \mathrm{i}=$ Pengaruh kelompok ke-i

aj = Pengaruh perlakuan ke-j

हij = Pengaruh galat percobaan pada kelompok ke-i, dan kelompok ke-j

Perbedaan antar perlakuan selanjutnya diuji dengan menggunakan Uji Jarak Berganda Duncan ( Steel dan Torrie, 1980). Analisis usahatani meliputi :

a. Pendapatan kotor usahatani, yaitu nilai uang yang dihasilkan dari penjualan produk usahatani dinyatakan dengan penerimaan kotor usahatani

b. Pendapatan bersih usahatani, yaitu dilakukan dengan menghitung selisih pendapatan kotor dengan seluruh pengeluaran tunai (biaya) usahatani

c. Net Benefit Cost Ratio (NBCR), yaitu pendapatan bersih dibagi dengan total cost, hasil perhitungan ini dimaksudkan untuk menilai kelayakan suatu sistem usahatani secara ekonomi.

\section{HASIL DAN PEMBAHASAN}

Hasil penelitian menunjukkan bahwa sistem olah tanah besar pengaruhnya terhadap biaya usahatani, pada tanah yang diolah akan terjadi penambahan biaya, hal ini berkaitan dengan besarnya biaya pada input tenaga kerja saat pengolahan tanah sehingga akan berpengaruh pada pendapatan usahatani, selain itu pada tanah yang diolah dapat terjadi erosi pada saat turun hujan sehingga unsur hara pada lapisan tanah atas akan tercuci akibatnya tanah akan berkurang kesuburannya dan produktivitas persatuan luas akan rendah sedangkan pada sistem tanpa olah 
tanah akan menyebabkan jumlah mulsa semakin besar sehingga erosi yang terjadi dapat ditekan (Bandel 1986). Bahkan menurut Sinukaban (1987) mampu mencapai 90 \%. Begitu juga dengan sistem pertanaman, pada sistem tumpang sari yang dikombinasikan dengan tanpa olah tanah hasil penelitian menunjukkan pendapatan usahatani lebih besar (Tabel 2), hal ini berkaitan bahwa sistem pertanaman dengan beberapa jenis tanaman yang dirotasikan secara tepat mempunyai keunggulan dalam memperbaiki sifat -sifat tanah

Biaya usahatani yang terbesar adalah pada biaya tenaga kerja untuk pengolahan tanah konvensional. Besarnya biaya tersebut dapat mengurangi pendapatan usahatani dari penerimaan usahatani yang diperolehnya. Untuk sistem pertanaman ternyata sistem tumpangsari lebih efisien dibanding dengan sistem monokultur karena biaya yang dikeluarkan dalam pemeliharaan usahatani pada sistem tumpangsari tidak berbeda dengan biaya pemeliharaan pada sistem monokultur.Sistem pertanaman pada musim pertama berpengaruh nyata terhadap produksi kedelai . Hasil biji kedelai tertinggi musim ke dua diperoleh pada monokultur jagung yang dikombinasikan dengan olah tanah minimum, sedang hasil jagung pipilan kering tertinggi diperoleh pada bera . Secara ekonomis bera musim pertama memberikan pendapatan bersih tertinggi pada musim ke dua, namun demikian semua perlakuan pada musim pertama dikategorikan layak untuk diterapkan karena mempunyai indeks rasio benefit cost lebih dari satu.

Tabel 1. Pengaruh Bera dan Kombinasi Sistem Olah Tanah dengan Pertanaman pada Musim Pertama Terhadap Produksi dan Pendapatan Usahatani Musim Ke Dua.

\begin{tabular}{|c|c|c|c|c|c|}
\hline \multirow[t]{2}{*}{ Perlakuan } & \multicolumn{3}{|c|}{ Produksi (kg/ha) } & \multirow{2}{*}{$\begin{array}{c}\text { Pendapan } \\
\text { bersih*)(Rp/ha) }\end{array}$} & \multirow[t]{2}{*}{ NBCR } \\
\hline & Kede & & Jagung & & \\
\hline Bera & 515 & $a$ & $3711 \quad a$ & $1.219 .383 \mathrm{a}$ & 2,16 \\
\hline OoT & 333 & $\mathrm{~cd}$ & $3240 \mathrm{~b}$ & $840.817 \mathrm{c}$ & 1,49 \\
\hline OoK & 337 & $\mathrm{~cd}$ & 3651 a & $969.550 \mathrm{bc}$ & 1,72 \\
\hline OoJ & 502 & $a b$ & $3230 \mathrm{~b}$ & $1.057 .317 b$ & 1,88 \\
\hline 01T & 326 & de & $3202 b$ & $822.383 \mathrm{C}$ & 1,46 \\
\hline 01K & 234 & e & $2756 \mathrm{c}$ & $566.917 \mathrm{~d}$ & 1,00 \\
\hline $01 \mathrm{~J}$ & 521 & a & 3047 bc & $1.027 .983 b$ & 1,82 \\
\hline O2T & 297 & de & $2757 \mathrm{c}$ & $649.117 \mathrm{~d}$ & 1,15 \\
\hline $\mathrm{O} 2 \mathrm{~K}$ & 239 & e & 2977 bc & $639.517 d$ & 1,13 \\
\hline $\mathrm{O} 2 \mathrm{~J}$ & 420 & $\mathrm{bc}$ & $3263 b$ & 960.717 bc & 1,70 \\
\hline
\end{tabular}

Keterangan :

Angka - angka pada kolom dan diikuti huruf yang sama tidak berbeda nyata padan taraf 5\% menurut uji DMRT.

00 : Tanpa olah tanah

$T$ : Tumpang sari

01 :Olah tanah $1 x$ (minimum)

K: Kedelai

02 :Olah tanah $2 x$ (konvensional)

$J$ : Jagung

*) Pendapatan kotor dihitung berdasarkan nilai harga kedelai Rp. 1.300,00 dan jagung Rp. 300,00 
Tingginya pendapatan bersih pada bera berkaitan erat dengan kemampuannya dalam mengkonservasi bahan organik dan mempertahankan kandungan hara tanah. Selama tanah dibiarkan bera banyak tumbuh rerumputan dan semak belukar yang daun-daunnya akan gugur ke tanah dan membusuk menjadi mulsa sehingga banyak menghasilkan bahan organik dan secara otomatis akan memberikan hara ke dalam tanah sehingga tanah menjadi subur, kondisi ini sangat mendukung pertumbuhan tanaman menjadi baik yang akan berpengaruh terhadap produksi tanaman dan pendapatan usahatani. Hasil perhitungan selama dua musim tanam menunjukkan bahwa total pendapatan bersih untuk bera nyata lebih rendah dibandingkan kombinasi tanpa olah tanah dengan sistem pertanaman yang diberikan .

Tabel 2. Pengaruh Bera dan Kombinasi Sistem Olah Tanah dan Pertanaman Terhadap Total Produksi, Pendapatan Bersih dan Indeks B-C Rasio Selama Dua Musim Tanam .

\begin{tabular}{|c|c|c|c|c|c|}
\hline \multicolumn{2}{|c|}{ Perlakuan } & \multicolumn{2}{|c|}{ Produksi (kg/ha) } & \multirow{2}{*}{$\begin{array}{c}\text { Pendapatan bersih*) } \\
\text { (Rp/ha) }\end{array}$} & \multirow[t]{2}{*}{ NBCR } \\
\hline MT. I & MT.II & Kedelai & Jagung & & \\
\hline Bera & 01T & 515 & 3711 & $1.219 .383 d$ & 2,16 \\
\hline O०T & 01T & 1273 & 6628 & $2.685 .833 \mathrm{a}$ & 2,49 \\
\hline $\mathrm{OOK}$ & 01T & 1844 & 3651 & $2.491 .317 \mathrm{a}$ & 2,51 \\
\hline OOJ & 01T & 502 & 7225 & $1.812 .817 \mathrm{~b}$ & 1,80 \\
\hline 01T & 01T & 914 & 5140 & $1.535 .967 \mathrm{c}$ & 1,30 \\
\hline $01 \mathrm{~K}$ & 01T & 1244 & 2756 & $1.339 .283 \mathrm{~cd}$ & 1,21 \\
\hline $01 \mathrm{~J}$ & 01T & 521 & 6247 & $1.446 .183 \mathrm{~cd}$ & 1,30 \\
\hline $\mathrm{O} 2 \mathrm{~T}$ & 01T & 855 & 4775 & $1.236 .600 \mathrm{~d}$ & 0,95 \\
\hline $\mathrm{O} 2 \mathrm{~K}$ & 01T & 1215 & 2977 & $1.281 .350 \mathrm{~d}$ & 1,82 \\
\hline O2J & $01 \mathrm{~T}$ & 420 & 6487 & $1.262 .817 \mathrm{~d}$ & 1,03 \\
\hline
\end{tabular}

Keterangan :

Angka - angka pada kolom yang sama dan diikuti huruf yang sama tidak berbeda nyata padan taraf $5 \%$ menurut uji DMRT. Pendapatan kotor dihitung berdasarkan nilai harga kedelai Rp 1.350,00 dan jagung Rp 1.350,00.
O0: Tanpa olah tanah
$T$ : Tumpang sari
01 :Olah tanah $1 x$ (minimum)
K: Kedelai
02 :Olah tanah $2 x$ (konvensional)
$J$ : Jagung

Hal ini berkaitan dengan perbedaan intensitas pertanaman yang mengakibatkan perbedaan pada produksi , intensitas pertanaman yang hanya dilakukan satu kali dengan periode bera satu kali mengakibatkan total produksi pada bera masih rendah dibandingkan perlakuan lainnya. Pada Tabel 2 dapat dilihat bahwa pendapatan bersih tertinggi diperoleh pada kombinasi tanpa olah tanah dengan pertanaman tumpangsari saat musim pertama dan olah tanah minimum dengan tumpangsari pada musim ke dua . Kondisi ini disebabkan rendahnya biaya yang dikeluarkan saat musim tanam pertama karena dengan tanpa olah tanah berarti sudah 
mengurangi input tenaga kerja dan dengan sistem tumpangsari sudah dapat lebih efisien dalam berusahatani sebagai akibat dari rendahnya input produksi (Cardero dan Mc Collum, 1978), begitu juga pada saat musim tanam ke dua dengan rendahnya biaya input dalam berusahatani dan kondisi tanah yang mendukung pertumbuhan dan hasil tanaman maka akan diperoleh penerimaan produksi yang tinggi dan pendapatan juga akan tinggi. Hal ini terlihat lebih tingginya hasi persatuan luas yang diperoleh pada kedelai dan jagung .

Adanya pertimbangan terhadap resiko usahatani, ternyata secara umum kombinasi sistem olah tanah dan pertanaman yang tergolong layak untuk diterapkan adalah dengan nilai indeks benefit cost ratio lebih besar dari satu, kecuali kombinasi sistem olah tanah konvensional dengan tumpangsari (Sukartawi dkk, 1983).Sistem olah tanah berpengaruh nyata terhadap pendapatan kotor dan pendapatan bersih pada sistem tumpang sari dan monokulturkedelai, sebaliknya tidak berpengaruh nyata pada monokultur jagung (Tabel 3 dan 4). Pendapatan kotor dan pendapatan bersih pada sistem tumpangsari dengan penerapan olah tanah konvensional dan olah tanah minimum nyata lebih rendah dibanding dengan tanpa olah tanah. Penurunan pendapatan kotor pada sistem tumpangsari pada olah tanah konvensional dan olah tanah minimum masing-masing sebesar $13,7 \%$ dan $1,4 \%$. Selanjutnya pendapatan kotor monokultur kedelai dengan penerapan olah tanah konvensional dan minimum masing-masing turun $21,1 \%$ dan $25,9 \%$.

Tabel 3. Pengaruh Sistem Olah Tanah dan Pertanaman serta Interaksinya Terhadap Pendapatan Kotor Usahatani Musim KeDua *

\begin{tabular}{lcccc}
\hline \multirow{2}{*}{ Sistem Olah Tanah } & \multicolumn{3}{c}{ Sistem pertanaman (Rp/ha) } & \multirow{2}{*}{ Rata - rata } \\
\cline { 2 - 4 } & Tumpang sari & Kedelai & Jagung & \\
\hline Tanpa olah & $1.405 .567 \mathrm{a}$ & $1.525 .233 \mathrm{a}$ & $1.621 .667 \mathrm{a}$ & 1.516 .956 \\
Olah Minimum & $1.386 .133 \mathrm{a}$ & $1.130 .667 \mathrm{~b}$ & $1.591 .733 \mathrm{a}$ & 1.369 .511 \\
Olah Konvensional & $1.212 .867 \mathrm{~b}$ & $1.203 .267 \mathrm{~b}$ & $1.524 .467 \mathrm{a}$ & 1.313 .533 \\
\hline Rata - rata & 1.334 .522 & 1.287 .056 & 1.579 .089 & \\
\hline
\end{tabular}

Keterangan:

Angka - angka pada kolom yang sama dan diikuti huruf yang sama tidak berbeda pada taraf nyata $5 \%$ uji DMRT *) Dihitung menurut niali jual produk usaha tani.

Variabel pendapatan bersih untuk tumpangsari dan monokultur kedelai nyata menurun dengan makin meningkatnya intensitas pengolahan tanah. Penerapan sistem olah tanah konvensional pada sistem tumpangsari mengakibatkan penurunan pendapatan bersih 22,7 \% dan penerapan olah tanah minimum hanya mengakibatkan penurunan sebesar $2,2 \%$. Selanjutnya 
penerapan olah tanah konvensional dan minimum pada monokultur kedelai mengakibatkan penurunan pendapatan bersih masing-masing 34,0\% dan 41,5 \%.Penurunan pendapatan usahatani musim ke dua untruk monokultur kedelai dengan pengolahan tanah minimum dan olah tanah konvensional diduga karena perbedaan produksi dan selisih harga yang cukup tinggi antara kedelai dan jagung. Harga produksi kedelai mempunyai selisih yang cukup besar yaitu Rp.1000/kg atau sekitar 285,7 \% lebih tinggi dibanding jagung, sehingga penurunan produksi kedelai mempunyai dampak cukup besar terhadap penurunan pendapatan usahatani.

Tabel 4. Pengaruh Sistem Olah Tanah dan Pertanaman serta Interaksinya Terhadap Pendapatan Bersih Usahatani pada Musim Ke Dua *

\begin{tabular}{ccccc}
\hline Sistem Olah Tanah & \multicolumn{3}{c}{ Sistem pertanaman (Rp/ha) } & \multirow{2}{*}{ Rata - rata } \\
\cline { 2 - 4 } & Tumpang sari & Kedelai & Jagung & \\
\hline Tanpa olah & $840.817 \mathrm{a}$ & $969.550 \mathrm{a}$ & $1.057 .317 \mathrm{a}$ & 955.894 \\
Olah Minimum & $822.383 \mathrm{a}$ & $566.917 \mathrm{~b}$ & $1.027 .983 \mathrm{a}$ & 805.761 \\
Olah Konvensional & $649.117 \mathrm{~b}$ & $639.517 \mathrm{~b}$ & $960.717 \mathrm{a}$ & 749.783 \\
\hline Rata - rata & 770.772 & 725.328 & 1.015 .339 & \\
\hline
\end{tabular}

Keterangan:

Angka - angka pada kolom yang sama dan diikuti huruf yang sama tidak berbeda pada taraf nyata $5 \%$ uji DMRT *) Pendapatan bersih merupakan selisih pendapatan kotor dengan biaya usaha tani.

Disamping itu produksi kedelai pada sistem monokultur kedelai musim tanam pertama lebih rendah dibanding sistem monokultur jagung, artinya produksi kedelai dengan rotasi kedelaikedelai lebih rendah dibanding rotasi jagung-kedelai. Hal ini berkaitan erat dengan perbedaan serapan hara yang mengakibatkan perbedaan kesuburan tanah. Hasil penelitian Sudana dan Basa (1985) menunjukkan bahwa pola tanam anjuran dengan lebih dari satu sistem tumpangsari dalam satu tahun dengan intensifikasi tanaman yang padat memberikan nilai pendapatan usahatani jauh lebih tinggi dibandingkan dengan hanya menggunakan satu kali tumpangsari dan tiga komoditi dalam satu tahun. Hasil penelitian Lal (1976) di Nigeria Barat yang menunjukkan bahwa produksi kedelai sistem kontinyu tanpa olah tanah pada musim pertama 0,86 tha turun menjadi 0,57 tha pada musim ke dua sedangkan pada sistem rotasi jagung kedelai ternyata produksi kedelai musim kedua lebih tinggi yaitu 0,79 t/ha. 


\section{KESIMPULAN}

Sistem tanpa olah tanah dan pertanaman tumpangsari memberikan hasil yang lebih baik terhadap pendapatan usahatani. Pengolahan tanah mengakibatkan terjadinya penurunan pendapatan usahatani musim ke dua pada sistem tumpangsari dan monokultur kedelai. Olah tanah minimum dan konvensional yang diterapkan pada sistem pertanaman tumpangsari menurunkan pendapatan kotor sebesar $13,7 \%$ dan 1,4 \%. Penurunan pendapatan bersih akibat olah tanah minimum dan konvensional untuk sistem tumpangsari masing-masing sebesar 22,7 $\%$ dan $2,2 \%$.

\section{DAFTAR PUSTAKA}

Bandel,V.A. 1986. Nitrogen Management for no-tillagecorn: In Phillips R.E. (eds) .Proc. of the Southern Kentucky.Lexington Kentucky. 1-5.

Cordero, A and R.E. MC.Collum.1978. Intercropping Research in North Carolina . AgronomicEconomic Research on soil of The Tropics Ann.Report for 1976-1977.Soil Science Dept. Nort Carolina StateUniv. Raleigh,N.C.

Griffith,D.R.,J.V. Mannering,H.M. Galloway,S.D. Parsons and CB. Richey. 1977. Effect of Eight Tillage Planting Systems on Soil Temperature Persentand.Plant Growth and Yields ofCorn on Five Indiana Soils.Agronomic J.65:321-326.

Hiebsch, C. 1978 Comparing Intercrope with mono cultures. Agronomic - Econimic Research non Soil of The Tropics. Ann. Report for 1976 - 1977. Soil Sci Dept. North Carolina State Univ. Raleigh. N. C

Larson. W. E. And . G. J. Osborn 1985. Tillage Accomplishment and Potentil In Predicting Tillage Effect On Soil Physical Properties and Processes. ASA. Special Publcation No 44. Madison. Wisconsin.

Sinukaban, N. 1987 . Pengolahan Tanah Konservasi Pada Pertanian Tanaman Padi dan Jagung. Prosiding Seminar Budidaya Pertanian Tanpa Olah Tanah . IPB. Bogor.

Soekartawi, A. Dkk 1983. IImu Usaha Tani Dan Penelitian Untuk Pengembangan Petani Kecil. UI Press.

Sudana dan Basa. 1984. Hasil Penelitian Usaha Tani Terpadu Di Daerah Transmigrasi Tulang Bawang. Prosiding Pertemuan Teknis Penelitian Pola Usaha Tani Menunjang Transmigrasi. Cisarua. Bogor.

Utomo. M. 1989. Budidaya Pertanian Tabpa Olah Tanah Untuk Pertanian Lahan Kering. Prosiding Seminar Budidaya Pertanian Tanpa Olah Tanah. IPB. Bogor.

Utomo. M. 1990. Budidaya Pertanian Tanpa Olah Tanah Teknologi Untuk Pertanian Berkelanjutan. Pertemuan Teknis Direktorat Bina Produksi. Departemen Pertanian. Jakarta. 